\title{
Emergency remote learning acceptance among higher education students during COVID-19 pandemic
}

\author{
Amila Pilav-Velićc ${ }^{\text {, Hatidža Jahić }}{ }^{2}$, Jasmina Okičic ${ }^{3}$, \\ Jasmina Selimovic ${ }^{4}$, Elvedin Grabovica ${ }^{5}$
}

\begin{abstract}
The current study investigates how attitudes towards digital transformation and personal innovativeness affect the acceptance of emergency remote learning in the COVID-19 pandemic environment. The pandemic has affected all aspects of societies across the globe, including higher education that was also a significant push-up factor for the digital transformation of higher education. Thus, the main aim of this paper is to investigate the factors affecting emergency remote learning acceptance among the higher education students in Bosnia and Herzegovina (BiH). The results presented in this paper gained from a study carried out among higher education students in BiH cover the period of April - July 2020 via the open-source platform. The study focused on the students' attitude towards a digital transformation is a significant factor in accepting emergency remote learning. Also, the personal
\end{abstract}

* Received: 02-10-2021; accepted: 17-12-2021

1 Associate professor, School of Economics and Business, University of Sarajevo, Trg oslobođenja - Alija Izetbegović 1, 71000 Sarajevo, Bosnia and Herzegovina. Scientific affiliation: innovation management, open innovation. Phone: +38733253771. E-mail: amila.pilav-velic@efsa.unsa.ba.

2 Assistant professor, School of Economics and Business, University of Sarajevo, Trg oslobođenja - Alija Izetbegović 1, 71000 Sarajevo, Bosnia and Herzegovina. Scientific affiliation: education, development economics.Phone:+38733253776.E-mail: hatidza.jahic@efsa.unsa.ba.

${ }^{3}$ Associate professor, Faculty of Economics, University of Tuzla, Univerzitetska 8, 75000 Tuzla, Bosnia and Herzegovina. Scientific affiliation: quantitative economics. Phone: +3876030444419.E-mail: jasmina.okicic@unitz.ba.

4 Professor, School of Economics and Business, University of Sarajevo, Trg oslobođenja Alija Izetbegović 1, 71000 Sarajevo, Bosnia and Herzegovina. Scientific affiliation: finance, insurance.Phone:+387332759921.E-mail: jasmina.selimovic@efsa.unsa.ba.

5 Assistant professor, School of Economics and Business, University of Sarajevo, Trg oslobođenja - Alija Izetbegović 1, 71000 Sarajevo, Bosnia and Herzegovina. Scientific affiliation: information systems. Phone: +38733275900. E-mail: elvedin.grabovica@efsa.unsa.ba. 


\begin{abstract}
innovativeness score has proven to be a crucial factor for adopting this new learning setting, i.e., more innovative students have a greater emergency remote learning acceptance than students with a lower personal innovativeness score. Hence, this study pinpoints the necessity of changing the attitudes towards technology applications in education. It would increase the usage of remote learning services and provide students with knowledge and skills for the new labour market.
\end{abstract}

Key words: personal innovativeness, remote learning, digital transformation, students, COVID-19

JEL classification: $121,123,033,036$

\title{
1. Introduction
}

A smart society is a society in which digital technology encourages the strengthening of three broad areas: (i) well-being and living standards of citizens; (ii) economic strength and prospects; (iii) efficiency of institutions/organizations/ companies operating within a society (Chakravorti et al., 2017). The role of digital technology in a smart society is not a final goal, but a means to achieve other higher goals of society. Therefore, accepting and using digital technology is a prerequisite for social growth and development in all segments of society. In other words, whether we are enthusiastic or indifferent to technology, we cannot deny that it is part of our daily lives and that we desperately need it (McCarthy and Wright, 2004). However, as Bouee (2015) pointed out, "success in the digital age does not lie in the efficiency of technology, but in the dexterity and adaptability of the people who use it". In other words, employees in the organization/company must learn how to use and adopt technology to increase company productivity (Venkatesh et al., 2003).

Before the pandemic, higher education institutions around the globe started with the implementation of different learning models: distance learning, online learning, blended learning, mobile learning, etc. However, the emergence of the COVID-19 pandemic has made universities completely switch to remote learning. All of these forms of learning are dependent on technological equipment, and hence, the provision of equipment was a big challenge for institutions, faculty, and learners (Adedoyin and Soykan, 2020). It was a stress test for the higher education system, lecturers, tutors, and students involved (Handel et al., 2020). Authors Hodges et al. (2020), Milman (2020), Rapanta et al. (2020) argue, remote teaching caused by the pandemic can only be understood as "an emergency remote teaching." Thus, in this research paper, we employ the concept of "an emergency remote learning" as students had neither choice to decide nor the time to prepare for this new environment. Hodges et al. (2020) indicate that emergency remote-teaching emerges as a response to a crisis and is a temporary shift of instructional delivery that involves the complete application of the remote models of instruction. "While this is a strong stress test for education systems, this is also an opportunity to develop alternative education opportunities" (OECD, 2020: 1). Today's generations 
of students across the globe require skills and competencies that will enable them to acquire existing and create new knowledge and technologies to meet future needs. As OECD (2021: 7) puts it: "our schools today are our economies tomorrow". A paradigm shift has occurred in university education (Garcia-Morales et al., 2021) and online education is here to stay (Adedoyin and Soykan, 2020).

The question that guided this study is how digital transformation, personal innovativeness, and specific personality traits affect the acceptance of emergency remote learning in higher education institutions. Dimensions examined in this study are (1) Students' innovativeness as defined by Zhou and George (2001) with a special focus on domain-specific innovativeness, i.e., Openness of access to digital transformation as in Agarwal and Prasad (1998), (2) Students' attitudes towards digital transformation as measured by Lu et al. (2005) and (3) Personality traits - Big Five Personality Traits test (Conscientiousness, Openness, Agreeableness, Extraversion, and Neuroticism) which will provide an additional basis for understanding students' attitudes and behaviour when using digital technology in their learning experience set in this changing global environment (Rammstedt and John, 2007). Taking into account all of the above, this study has the following specific research objectives:

RO1. To determine the statistically significant difference between the propensity towards remote learning and selected factors.

RO2. To explain the factors that influence the likelihood of the propensity towards remote learning.

With a growing body of research on the impact of an individual's sociodemographic characteristics on his/her digital abilities and attitude towards digital transformation, few have focused exclusively on examining these characteristics in the category of students at higher education level, i.e., universities, and none in the context of emergency remote learning caused by COVID-19 pandemic. This statement especially refers to Bosnia and Herzegovina (BiH), where scientific research in the field of digitalization is at a very low level compared to European and global contemporary research in the same scientific field. Empirically speaking, this research paper addresses the category of higher education students in $\mathrm{BiH}$ at two cycles, i.e., first cycle (undergraduate - bachelor level), second cycle (graduate - master level), their innovativeness, and digital transformation in the emergency remote learning caused by the COVID-19 pandemic. Results show, among other things, a significant association between remote learning, digital transformation, and personal innovativeness, but also different digital transformation scores, among different groups of respondents. Thus, we also provide important practical implications for future research.

The rest of the paper is structured as follows. Section 2 reviews previous studies by investigating digital transformation, personal innovativeness, and personality traits 
in the learning environment and explains our hypothesis development. In Section 3, we describe our methodological framework. In Section 4, we discuss the empirical data and the analysis. Section 5 discusses the key findings of this. Lastly, Section 6 provides concluding remarks with policy implications, limitations of the research and recommendations for the future studies in the field.

\section{Literature review}

Students' acceptance of remote learning various due to several factors. These factors are divided for this research paper into main categories: personal innovativeness, personal traits and digital transformation.

\subsection{Personal innovativeness and domain-specific personal innovativeness}

Contemporary literature that deals with the conceptualization of personal innovativeness describe personal innovativeness as a key determinant in the innovation adoption process. Agarwal and Prasad (1998) made a significant contribution by introducing personal innovation as a separate dimension that deepens the understanding of how an individual's attitude toward digital technology is formed. People with pronounced personal innovation are more likely to not only embrace digital technology but also to act as leaders and motivators within their society and encourage others to start using and embracing innovation (Rogers, 1995). Moreover, a person is considered innovative if he/she is willing to accept innovation at an early stage or soon after its appearance in society (Rogers and Shoemaker, 1971a; Rogers 1995). However, domain-specific innovativeness was found to predict innovative user behaviour more accurately (Leavitt and Walton, 1975). First launched by Goldsmith and Hofacker (1991) and later applied in different industries such as fashion (Goldsmith et al., 2005) and information technology (Agarwal and Prasad, 1998; Agarwal and Karahanna, 2000).

Domain-specific conceptualization of Personal Innovativeness in Information Technology (PIIT), defined by Agarwal and Prasad (1998), deals with innovative individuals as early adopters of innovations. These individuals have more positive perceptions and beliefs about innovation, particularly in the scope of new technology. Defined by Lu et al. (2005) PIIT symbolizes risk-taking propensity, characteristic just for particular individuals. Also, personal innovativeness implies risk-taking propensity, and these individuals can cope with high levels of uncertainty (Bruner and Kumar, 2005; Hwang, 2014). Other characteristics of innovative individuals also include knowledge self-efficacy (Lin and Hwang, 2014); self-confidence in performing new tasks (Kegerreis et al., 1970); computer self-efficacy (Thatcher and Perrewe, 2002); openness towards mobile learning (Joo et al., 2014) and early technology adopters (Rogers and Shoemaker, 1971b; 
Rogers, 2003). Undergraduate students have stronger preferences for online courses than graduate students. Also, married students reported lower levels of anxiety/ frustration with online courses (Keller and Karau, 2013). When it comes to students, personal innovativeness in the domain of information technology represents a significant factor in explaining the students' perception of the technology and their intent to use the technology in the learning process (Fagan et al., 2012). Based on the above-discussed arguments, the following hypothesis is proposed:

H1: Personal innovativeness may be considered as an antecedent of the propensity towards emergency remote learning.

\subsection{Digital transformation and remote learning: attittudes and acceptance}

The characteristics of the technology whose adoption is being examined significantly affect the attitude of individuals toward technology. Such and similar findings have motivated the development of different models for examining the acceptability of technologies. Some of them include Theory of Reasoned Action - TRA (Hale et al., 2002); Technology Acceptance Model - TAM (Chuttur, 2009); Theory of Planned Behavior - TPB (Ajzen, 1991); Model of Adoption of Technology in Households - MATH (Fillion and Le Dinh, 2008); Motivational Model - MM (Samaradiwakar and Gunawardena, 2014). The Unified Theory of Acceptance and Use of Technology (UTAUT) holds four key constructs, namely: (i) performance expectancy, (ii) effort expectancy, (iii) social influence, and (iv) facilitating conditions. However, UTAUT2 has added three additional constructs: hedonic motivations, price value, and habit (Venkatesh et al., 2012). This model shows that acceptance depends on four basic variables: 1. Expected results; 2. Expected use effort; 3. Social impact; and 4. Facilitating conditions in access to technology. These four variables affect IT acceptance, and they change according to the four basic factors: 1. Gender of the individual; 2. Age of the individual; 3. Individual experience; and 4. Will (willingness) to use (Venkatesh et al., 2003).

Vekantesh (2000) found a positive correlation between the level of education and the expected results of the use of technology, stating that more educated people recognize the greater usefulness of innovation. In addition, England and Stewart (2007) state that the introduction of new technology (product/innovation) plays a key role in creating a positive perception of the use of technology, i.e., that the characteristics of the technology whose acceptance is examined are a very important determinant in decision making for future technology users (Tolba and Mourad, 2011). Similarly, Rogers $(1962 ; 2003)$ states that the adoption of innovation highly depends on the perception of the characteristics of the innovation and the adopter's situation. In fact, the perceived usefulness and ease of use are considered important factors for technology acceptance (Rodrigues-Ardura and Meseguer-Artola, 2016). Regarding the usage, technology that is easy to use is more likely to be perceived 
as useful (Fagan et al., 2012). Also, the technology acceptance model shows that an individual's perception of the ease of use and usefulness significantly influence the individual's intention to use information technology applications (Davis, 1989). Thus, it can be derived that technology that is easy to use is more likely to be perceived as useful (Fagan et al., 2012).

Digital competence is understood as the student's ability to access and use technology to consume and evaluate the information for further production and communication with different digital tools and media (He and $\mathrm{Zhu}, 2017)$. Its close relationship with students' ICT self-efficacy with a focus on the user's perception of its capabilities to use ICT to achieve intended outcomes is shown in Venatesh et al. (2003). Furthermore, previous studies (Hatlevik and Christophersen, 2013; Park, 2009; Park et al., 2012) show a significant influence of computer selfefficacy on students' adoption of digital tools and applications for learning. Open access to online education (as a form of remote learning) allows students to develop a learning system that is more skill-oriented (Harvey and Slaughter, 2007). Technology is not a supplemental teaching tool but an essential one to successful performance outcomes (Ertmer and Ottenbreit-Leftwich, 2010), and we add to that a positive attitude towards digital transformation as a precondition for acceptance of remote learning. Based on these assumptions, we hypothesize the following:

H2: Propensity towards digital transformation may be considered as an antecedent of the propensity towards emergency remote learning.

\subsection{The effects of personality}

Personality researchers have expressed high levels of consensus on the value of the Big Five dimensions (Openness, Conscientiousness, Extraversion, Agreeableness, and Emotional Stability) in the process of studying (Keller and Karau, 2013). For a long time, it has been used as a predictor of performance and preferences in different educational environments (Poropat, 2009). Personality has been analysed in the context of students' academic performance in different disciplines (Borg and Shapiro, 1996; Chowdhury and Amin, 2006). The common conclusion of these studies has been that personality affects academic performance and that the importance of different dimensions differs among these studies, i.e., disciplines.

The existence of the influence of the five personality dimensions on digital literacy and the individual's attitude towards digital transformation has already been dealt with in several previous studies. The relationship between personality traits and attitudes towards the acceptance of innovation in terms of two dimensions, perceived usefulness and perceived ease of use, is expressed and strong (Ozbek et al., 2014; Khan et al., 2011). Namely, the researchers found that while comfort positively affects perceived usefulness, neuroticism has a negative relationship to the stated dimension. Furthermore, openness to experience and conscientiousness positively affect 
perceived utility and perceived ease of use of technology (Ozbek et al., 2014; Khan et al., 2011). The specific relationship between personality and academic performance in the context of online and distance learning has been analyzed by a significant number of authors. Most of them have found this relationship as strong while the significance of some personality dimensions varies from one author to another. These results can be found in Butler and Pinto-Zipp (2005); Kanuka and Nocente (2003); Lee and Lee (2006); Rovai (2003); Schniederjans and Kim (2005); Downing and Chim (2004), Keller and Karau (2013) and others.

Building on these arguments, we propose the following hypothesis:

H3: Personality traits may be considered as an antecedent of the propensity towards remote learning.

\section{Methodology}

The authors used the following probit model as a primary methodological approach:

$$
\begin{aligned}
e= & \beta_{0}+\beta_{1} \text { Propensity towards digital transformation }+ \\
& +\beta_{2} \text { Personal innovativeness }+\beta_{3-7} \text { Personality traits }+ \\
& +\beta_{8-10} \text { Demographic Characteristics }
\end{aligned}
$$

Estimation of the model was made by using STATA version 14. Prior to estimating the probit model, we will use the chi-square test of independence to examine the association of the propensity towards digital transformation, personal innovativeness, personality traits, and demographic characteristics with the propensity towards emergency remote learning. The null ( $\mathrm{H} 0)$ and alternative hypothesis (H1) of the chi-square test of independence are expressed as follows:

$\mathrm{H}_{0}$ : Propensity towards emergency remote learning is independent of propensity towards digital transformation/personal innovativeness/ personality traits/demographic characteristics

$\mathrm{H}_{1}$ : Propensity towards emergency remote learning is not independent of propensity towards digital transformation/personal innovativeness/ personality traits/demographic characteristics

The test statistic for the chi-square test of independence $\left(\chi^{2}\right)$ is calculated by using following formula:

$$
\chi^{2}=\sum_{i=1}^{k} \frac{\left(O_{i}-E_{i}\right)^{2}}{E_{i}},
$$

where $O_{i}$ stands for observed values and $E_{i}$ for expeced values. 
Furthermore, in order to measure the strength of the linear relationship between quantitative variables (emergency remote learning, digital transformation, personal innovativeness) and to compute their association we will use correlation analysis. The correlation coefficient $(r)$ is calculated by using the following formula:

$$
r=\frac{\operatorname{cov}_{x y}}{\sigma_{x} \sigma_{y}}
$$

where $\operatorname{cov}_{x y}$ stands for covariance between two variables, and $\sigma_{x} \sigma_{y_{i}}$ for the product of their standard deviations. The null hypothesis is that the population correlation coefficient is not significantly different from zero. Finally, we'll compare the means of two groups using the independent samples t test to see if there's statistical evidence that the associated population means are significantly different. The null hypothesis is that the difference between the two population means is equal to 0 .

\section{Empirical data and analysis}

\subsection{Data source and sample}

Using the purposive sampling technique, data collection was carried out among students from $\mathrm{BiH}$, during the summer semester of 2020, from April to July 2020, yielding a sample of 273 valid responses. Table 1 contains an overview of the basic characteristics of the sample.

Table 1: Overview of basic characteristics of the sample

\begin{tabular}{|l|l|c|c|}
\hline \multicolumn{2}{|c|}{ Characteristic } & Frequency & Per cent \\
\hline \multirow{4}{*}{ Gender } & Male & 68 & 26.4 \\
\cline { 2 - 4 } & Female & 190 & 73.6 \\
\cline { 2 - 4 } & Total & 273 & 100.0 \\
\hline \multirow{4}{*}{ Study cycle } & The first cycle & 188 & 68.9 \\
\cline { 2 - 4 } & The second cycle & 85 & 31.1 \\
\cline { 2 - 4 } & Total & 273 & 100.0 \\
\hline \multirow{4}{*}{ Age } & $\leq 21$ & 90 & 33.0 \\
\cline { 2 - 4 } & $21+$ & 183 & 67.0 \\
\cline { 2 - 4 } & Total & 273 & 100.0 \\
\hline
\end{tabular}

Source: Authors' work 
The data collection instrument is a structured questionnaire with closed questions, divided into several sections. The first section addresses Internet usage and digital literacy, while the second section addresses personal innovativeness followed by emergency remote learning dimension and demographic and other relevant data.

\subsection{Instrument validity}

The scores for each subscale were calculated as the total score for the items representing each dimension. However, before that, we assessed whether the subscales had satisfactory reliability (Table 2 ).

Table 2: Scale statistics

\begin{tabular}{|l|c|c|c|c|c|}
\hline \multicolumn{1}{|c|}{ Measure } & $\mathrm{N}$ & $\begin{array}{c}\text { Number of } \\
\text { items }^{6}\end{array}$ & $\mathrm{Mdn}$ & $\begin{array}{c}\text { Standard } \\
\text { deviation }\end{array}$ & $\begin{array}{c}\text { Cronbach's } \\
\text { Alpha }\end{array}$ \\
\hline $\begin{array}{l}\text { Emergency remote } \\
\text { learning }\end{array}$ & 273 & 9 & 34.00 & 7.67 & 0.928 \\
\hline Digital transformation & 273 & 4 & 13.00 & 3.22 & 0.801 \\
\hline Personal innovativeness & 273 & 5 & 19.00 & 3.68 & 0.826 \\
\hline
\end{tabular}

Source: Authors' work

Cronbach's Alpha is a measure of reliability that ranges from 0 to 1 , with values of 0.60 to 0.70 deemed the lower limit of acceptability (Hair et al., 2014). Having that in mind, it may be concluded that all scales had an acceptable level of reliability. Furthermore, the scores for each subscale were calculated as a total score for the items representing each dimension, i.e., emergency remote learning, digital transformation, and personal innovativeness.

\subsection{Variables}

Overview and description of variables are presented in Table 3.

\footnotetext{
6 Emergency remote learning was operationalized by the following items that refer to the: online teaching system; learning platform; satisfaction and experience with online learning system; teaching contents. Digital transformation was operationalized by the items that refer to: new information technology; experimenting with new information technologies Personal innovativeness was operationalized by some of the following items: new and practical ideas for improvement; new technologies, processes, techniques and/or product ideas; risk-taking and others. In all cases 5 point Likert scale was used ranging from absolute disagreement to absolute agreement.
} 
Table 3: Variables

\begin{tabular}{|c|c|c|c|}
\hline Variables & $\begin{array}{l}\text { Type of } \\
\text { variable }\end{array}$ & Description & Categories \\
\hline $\begin{array}{l}\text { Propensity toward } \\
\text { emergency remote } \\
\text { learning }\end{array}$ & Categorical & $\begin{array}{l}\text { Dependant variable based on the } \\
\text { median value of remote learning } \\
\text { score. If the emergency remote } \\
\text { learning score was above median } \\
(M d n>34) \text {, the value of dummy } \\
\text { variable was } 1 \text {, and } 0 \text { if the score } \\
\text { was equal and below median } \\
(M d n \leq 34) \text {. }\end{array}$ & $\begin{array}{l}\mathrm{D}=1 \text { if the } \\
\text { respondent } \\
\text { has above- } \\
\text { average positive } \\
\text { attitude towards } \\
\text { emergency remote } \\
\text { learning, } \\
0 \text { otherwise }\end{array}$ \\
\hline $\begin{array}{l}\text { Propensity } \\
\text { toward digital } \\
\text { transformation }\end{array}$ & Categorical & $\begin{array}{l}\text { Independent variable based } \\
\text { on the median value of digital } \\
\text { transformation score. If the score } \\
\text { was above median }(M d n>13) \text {, the } \\
\text { value of dummy variable was } 1 \text {, } \\
\text { and } 0 \text { if the score was equal and } \\
\text { below median }(M d n \leq 13) \text {. }\end{array}$ & $\begin{array}{l}\mathrm{D}=1 \text { if the } \\
\text { respondent has } \\
\text { above-average } \\
\text { positive attitude } \\
\text { towards digital } \\
\text { transformation, } \\
0 \text { otherwise }\end{array}$ \\
\hline $\begin{array}{l}\text { Personal } \\
\text { innovativeness }\end{array}$ & Categorical & $\begin{array}{l}\text { Independent variable created } \\
\text { based on the median value of } \\
\text { personal innovativeness score. } \\
\text { If the score was above median } \\
(M d n>19) \text {, the value of dummy } \\
\text { variable was } 1 \text {, and } 0 \text { if the score } \\
\text { was equal and below median } \\
(M d n \leq 19) \text {. }\end{array}$ & $\begin{array}{l}\mathrm{D}=1 \text { if the } \\
\text { respondent } \\
\text { has above- } \\
\text { average personal } \\
\text { innovativeness } \\
\text { score, } 0 \text { otherwise }\end{array}$ \\
\hline Openness & Categorical & $\begin{array}{l}\text { Derived from the question in the } \\
\text { survey related to openness as } \\
\text { a personality trait. Independant } \\
\text { variable based on the median value } \\
\text { of openness score. If the score was } \\
\text { above median }(M d n>2) \text {, the value } \\
\text { of dummy variable was } 1 \text {, and } 0 \\
\text { if the score was equal and below } \\
\text { median }(M d n \leq 2) \text {. }\end{array}$ & $\begin{array}{l}\mathrm{D}=1 \text { if the } \\
\text { respondent has } \\
\text { above-average } \\
\text { openness score, } \\
0 \text { otherwise }\end{array}$ \\
\hline Conscientiousness & Categorical & $\begin{array}{l}\text { Derived from the question in the } \\
\text { survey related to conscientiousness } \\
\text { as a personality trait. Independant } \\
\text { variable based on the median value } \\
\text { of conscientiousness score. If the } \\
\text { score was above median }(M d n>4) \text {, } \\
\text { the value of dummy variable was } \\
1 \text {, and } 0 \text { if the score was equal and } \\
\text { below median }(M d n \leq 4) \text {. }\end{array}$ & $\begin{array}{l}\mathrm{D}=1 \text { if the } \\
\text { respondent has } \\
\text { above-average } \\
\text { conscientiousness } \\
\text { score, } 0 \text { otherwise }\end{array}$ \\
\hline
\end{tabular}


Amila Pilav-Velić et al. Emergency remote learning acceptance among higher...

\begin{tabular}{|c|c|c|c|}
\hline Variables & $\begin{array}{l}\text { Type of } \\
\text { variable }\end{array}$ & Description & Categories \\
\hline Extraversion & Categorical & $\begin{array}{l}\text { Derived from the question in the } \\
\text { survey related to extraversion as } \\
\text { a personality trait. Independant } \\
\text { variable based on the median value } \\
\text { of extraversion score. If the score } \\
\text { was above median }(M d n>4) \text {, the } \\
\text { value of dummy variable was } 1 \text {, } \\
\text { and } 0 \text { if the score was equal and } \\
\text { below median }(M d n \leq 4) \text {. }\end{array}$ & $\begin{array}{l}\mathrm{D}=1 \text { if the } \\
\text { respondent has } \\
\text { above-average } \\
\text { extraversion score, } \\
0 \text { otherwise }\end{array}$ \\
\hline Agreeableness & Categorical & $\begin{array}{l}\text { Derived from the question in the } \\
\text { survey related to the agreeableness } \\
\text { as a personality trait. Independant } \\
\text { variable has based on the median } \\
\text { value of agreeableness score. If } \\
\text { the score was above median } \\
(M d n>1) \text {, the value of dummy } \\
\text { variable was } 1 \text {, and } 0 \text { if the score } \\
\text { was equal and below median } \\
(M d n \leq 1) \text {. }\end{array}$ & $\begin{array}{l}\mathrm{D}=1 \text { if the } \\
\text { respondent has } \\
\text { above-average } \\
\text { agreeableness } \\
\text { score, } 0 \text { otherwise }\end{array}$ \\
\hline Neuroticism & Categorical & $\begin{array}{l}\text { Derived from the question in the } \\
\text { survey related to neuroticism as } \\
\text { a personality trait. Independant } \\
\text { variable based on the median value } \\
\text { of neuroticism score. If the score } \\
\text { was above median }(M d n>2) \text {, the } \\
\text { value of dummy variable was } 1 \text {, } \\
\text { and } 0 \text { if the score was equal and } \\
\text { below median }(M d n \leq 2) \text {. }\end{array}$ & $\begin{array}{l}\mathrm{D}=1 \text { if the } \\
\text { respondent has } \\
\text { above-average } \\
\text { neuroticism score, } \\
0 \text { otherwise }\end{array}$ \\
\hline Age & Categorical & $\begin{array}{l}\text { Derived from the question in the } \\
\text { survey related to age. }\end{array}$ & $\begin{array}{l}1-\leq 21 \text { years } \\
2-21+\text { years }\end{array}$ \\
\hline Gender & Categorical & $\begin{array}{l}\text { Derived from the question in the } \\
\text { survey related to gender. }\end{array}$ & $\begin{array}{l}\mathrm{D}=1 \text { if the } \\
\text { respondent is } \\
\text { female, } \\
0 \text { otherwise }\end{array}$ \\
\hline The study cycle & Categorical & $\begin{array}{l}\text { Derived from the question in the } \\
\text { survey related to the study cycle. }\end{array}$ & $\begin{array}{l}1-\text { the first study } \\
\text { cycle } \\
2-\text { the second } \\
\text { study cycle }\end{array}$ \\
\hline
\end{tabular}

Source: Authors' work 


\subsection{Empirical analysis}

Within this chapter, the authors will present the results of the empirical research. In the first step of the analysis, we examined the association between selected variables. Results of the Pearson correlation indicated that there was a significant, positive association between the propensity toward emergency remote learning and digital transformation $(\mathrm{r}=.180, \mathrm{p}=0.003)$; propensity toward emergency remote learning and personal innovativeness $(\mathrm{r}=.182, \mathrm{p}=0.003)$, and between digital transformation score and personal innovativeness score, $(\mathrm{r}=.537, \mathrm{p}=0.000)$.

In the next step of the analysis, the personal innovativeness and digital transformation scores of two groups of respondents with a different propensity toward emergency remote learning were compared. On average, the group with the above-average propensity towards emergency remote learning $(M=19.46$, $S D=3.54$ ) had a higher personal innovativeness score compared to the other group $(M=17.78, S D=3.21)$. This difference was statistically significant $\mathrm{t}(228.57)=$ $-4.712, \mathrm{p}=0.000$ ). When it comes to digital transformation, on average, the group with the above-average propensity towards emergency remote learning $(M=14.08$, $S D=3.26)$ had a higher score compared to the other group $(M=12.76, S D=3.03)$. This difference was statistically significant $(\mathrm{t}(259)=-4.563, \mathrm{p}=0.000)$.

Furthermore, the personal innovativeness and emergency remote learning scores of two groups of respondents with a different propensity toward digital transformation were compared. On average, the group with the above-average propensity towards digital transformation $(M=20.05, S D=3.01)$ had a higher personal innovativeness score compared to the other group $(M=16.93, S D=3.58)$. This difference was statistically significant $\mathrm{t}(271)=-3.215, \mathrm{p}=.000)$. When it comes to emergency remote learning, on average, the group with the above-average propensity towards digital transformation $(M=35.77, S D=7.30)$ had a higher score compared to the other group $(M=31.98, S D=7.58)$. This difference was statistically significant $(\mathrm{t}(259)=-3.783, \mathrm{p}=0.000)$.

Finally, a chi-square test of independence was performed to examine the difference between propensity towards remote learning and propensity towards digital transformation and socio-demographic variables, i.e., age, gender and study cycle. We found a statistically significant difference between the propensity towards emergency remote learning and age, $\chi^{2}(1, N=261)=16.707, p<0.01$ and the propensity towards emergency remote learning and study cycle, $\chi^{2}(1, N=261)=9.998, p<0.05$.

When it comes to the propensity towards digital transformation, results of a chisquare test of independence are pointing to a statistically significant difference between this type of propensity and study cycle, $\chi^{2}(1, N=273)=11.949, p<0.001$.

To evaluate the impact of the selected independent variables on the likelihood of propensity towards emergency remote learning, the probit model was used. The 
goodness-of-fit was evaluated using the following measures: Pearson chi-square statistics, Hosmer and Lemeshow goodness-of-fit test, classification tables and pseudo $\mathrm{R}^{2}$. The results of the Pearson chi-square statistics verified the whole model (with all predictors included) as statistically significant $(\mathrm{p}=0.000)$. This model as a whole matches substantially better than a model without predictors. The Hosmer and Lemeshow goodness-of-fit test $(\mathrm{p}=0.5172)$ also verified this. According to the classification tables, model correctly classifies $70.45 \%$ of cases. Table 4 displays the results of the estimated model with marginal effects included.

Table 4: The estimated model with marginal effects

\begin{tabular}{|l|c|c|c|c|c|c|c|c|c|}
\hline \multicolumn{1}{|c|}{ Independent variables } & B & S.E & p. & MEMs & S.E. & $p$ & AMEs & S.E. & $p$ \\
\hline Digital transformation & 0.593 & 0.185 & 0.001 & 0.228 & 0.069 & 0.001 & 0.207 & 0.065 & 0.001 \\
\hline Personal innovativeness & 0.442 & 0.188 & 0.019 & 0.172 & 0.073 & 0.022 & 0.153 & 0.067 & 0.022 \\
\hline Personality Traits & 0.078 & 0.177 & 0.660 & 0.030 & 0.069 & 0.660 & 0.026 & 0.058 & 0.660 \\
\hline Openness & 0.393 & 0.231 & 0.089 & 0.155 & 0.091 & 0.088 & 0.134 & 0.079 & 0.092 \\
\hline Conscientiousness & -0.046 & 0.210 & 0.826 & -0.018 & 0.081 & 0.825 & -0.015 & 0.069 & 0.825 \\
\hline Extraversion & 0.103 & 0.183 & 0.573 & 0.040 & 0.071 & 0.573 & 0.339 & 0.059 & 0.571 \\
\hline Agreeableness & -0.072 & 0.186 & 0.700 & -0.028 & 0.072 & 0.700 & -0.024 & 0.062 & 0.701 \\
\hline Neuroticism & 0.571 & 0.214 & 0.008 & 0.214 & 0.076 & 0.005 & 0.193 & 0.071 & 0.006 \\
\hline Age & -0.003 & 0.200 & 0.990 & -0.001 & 0.078 & 0.990 & -0.001 & 0.066 & 0.990 \\
\hline 21+ & \multicolumn{7}{|l|}{$\mid$} \\
\hline Gender & 0.214 & 0.211 & 0.310 & 0.084 & 0.083 & 0.312 & 0.073 & 0.073 & 0.321 \\
\hline Female & -1.242 & 0.311 & 0.000 & - & - & - & - & - & - \\
\hline Study cycle
\end{tabular}

Note: MEMs - Marginal effect at the mean; AMEs - Average marginal effects

Source: Authors' work

As it can be seen from the previous table, the following variables prove to be statistically significant: digital transformation $(\mathrm{p}<0.01)$, personal innovativeness $(\mathrm{p}<0.05)$, and age $(\mathrm{p}<0.01)$.

Out of these three statistically significant factors, attitude towards digital transformation is the strongest predictor of the propensity toward emergency remote learning. Speaking of it, the predicted likelihood of a propensity toward emergency remote learning is $22.80 \%$ greater for those respondents who have an aboveaverage positive attitude towards digital transformation compared to those who do not. The expected change is statistically significant $(\mathrm{p}<0.05)$. 
When it comes to personal innovativeness, the predicted likelihood of propensity toward emergency remote learning is $22.80 \%$ greater for those respondents whose personal innovativeness score is above average. The expected change is statistically significant $(\mathrm{p}<0.05)$. Finally, when it comes to age, the predicted likelihood of propensity toward emergency remote learning is $21.40 \%$ greater for respondents who are over 21 years old comparing to younger ones. The expected change is statistically significant $(\mathrm{p}<0.05)$.

\section{Results and discussion}

This research study reveals that the attitude towards digital transformation is the strongest predictor of the propensity toward emergency remote learning. These findings are following the findings of Lai et al. (2012) who have shown that the attitude to technology usage has a significant effect on university students' learning with technology. This trait is considered to be an important factor in researching the adoption of technology in mobile, online and e-learning processes (Celik and Yesilyurt, 2013; Lai et al., 2012). Dabbagh and Kitsantas (2012) agree that a positive attitude towards technology is needed for successful participation in the learning process. He and $\mathrm{Zu}$ (2017) found that attitude mediates the impact of personal innovativeness and digital competencies (or digital literacy) on students' behaviour in digital informal learning. None of the tested personality traits is statistically significant in the propensity toward remote learning model. Previous studies in this area are also inconsistent as discussed in the literature review.

Personal innovativeness may be considered as an antecedent of the propensity towards emergency remote learning according to the results of this research study. These findings are following the findings of $\mathrm{He}$ and $\mathrm{Zu}$ (2017) who identified students' personal innovativeness and digital competences as important factors and found their direct effects on digital informal learning among Chinese university students. Personal innovativeness was also measured by using Liu et al. (2010) threeitem scale with adjustments to fit the local context. In line with this, Cheng (2014), Liu et al. (2010), while analysing digital informal learning, found a significant effect of personal innovativeness on this form of learning. In this area of research, many studies have analysed the attitude towards technology and found a significant effect on the university level students learning with technology (Lai et al., 2012).

Previous studies also analysed students' personal traits and found influence of personal innovativeness on mobile media for informal learning in higher education specifically (Cheng, 2014; Liu et al., 2010), while Joo et al. (2014) found a significant influence on user satisfaction and future intentions to continue mobile learning. Furthermore, Raaij and Schepers (2008) found that personal innovativeness reduces anxiety that surrounds computer usage and includes an open 
attitude to change and thus resulting in a higher tendency for technology usage in a virtual environment. Meyers et al. (2013) and Ungerer (2016), when analysing the same effect, came to the conclusion that digital competence and personal innovativeness may directly influence digital informal learning and also indirectly impact students' informal digital learning through attitude.

This study shows that there is no statistically significant difference between men and women in their propensity towards emergency remote learning. Two possible explanations for this could be that (a) students have been "forced" to emergency remote learning due to the COVID-19 pandemic and (b) the digital gap between male and female university students is narrowing. Our findings in this aspect are consistent with previous studies by Gabriel et al. (2012) and He and Zhu (2017) that found no differences between male and female university students regarding the time they spent on daily computer use and digital informal learning study. Furthermore, Markauskaite (2006) and Hatlevik and Christopherson (2013) found no differences between male and female digital competences. Finally, the Big five personality test was used for the purpose of studying personality effects on emergency remote learning. This study found no significant effects of personality traits on the propensity towards emergency remote learning. Kanuka and Nocente (2003) concluded that students' strong attraction to flexibility and convenience of online learning caused them to be satisfied regardless of their specific personality traits. Similarly, in line with the convenience of online learning environment, Downing and Chim (2004) highlight that individuals who are regarded as introverts in a class environment, become extroverts in an online setting. This could be a possible explanation for the lack of personality traits in our study in emergency remote learning setting. Consistent with these findings, university students whose personal innovativeness score is higher are more likely to accept new learning environment(s). Technology is not a supplemental teaching tool but rather an essential one when it comes to successful performance outcomes, i.e., student learning (Ertmer and Ottenbreit-Leftwich, 2010). This has never been more true than today. Thus, technology is essential in absorption of existing knowledge to create new knowledge and technologies. Digital competencies not only show students' ability to use technology in accessing and consuming information but they also show how students use technology to process, acquire and evaluate gathered information (Hatlevik and Christophersen, 2013).

\section{Conclusions}

The present study analysed the effect of digital transformation, personal innovativeness and personal traits on emergency remote learning. It can be concluded that digital transformation, personal innovativeness and the age of universitylevel students are significant factors when analysing propensity towards emergency remote learning. This implies that students with positive attitudes towards digital 
transformation, and highly innovative students have a higher propensity towards emergency remote learning at the university level. Our study provides a significant contribution in analysing the effect of personal on emergency remote learning acceptance at the university level. This fills the existing gap in the literature investigating the effect of factors such as attitude towards digital transformation, personal traits and personal innovativeness on the acceptance of emergency remote learning caused by the COVID-19 pandemic at high education level.

This study also has limitations. Firstly, the study is limited by its sample since it focuses only on university level students in the emergency remote learning environment. A possible limitation of this study is the sample type, i.e., convenience sample that limits the generalization of the findings since the research focuses on university students in $\mathrm{BiH}$. Also, the study is based on the self-reporting questionnaire. Thus, one should be cautious about generalization of findings in this study. The COVID-19 pandemic has changed learning methods at all education levels (primary and secondary),. Therefore,future studies need to address these levels as well. Future research on the digital transformation of education due to the COVID-19 pandemic should also include other aspects of social and academic life. Possible differences of prior levels of digitalization among the surveyed higher education institutions should be taken into account via qualitative analysis through semi-structured interviews.. Future studies should focus on specific student categories such as students with disabilities and investigate their acceptance of emergency remote learning for this group and other vulnerable or potentially excluded groups. This would provide a valuable insight for a better design of specific studies and/or courses. Investigation of students' academic performance and career prospects prior to and after the pandemic is of a significant interest for researchers and educators today. Finally, considering the concept of emergency remote learning, future research should focus more on the teachers' side of emergency remote learning and the factors that have affected their adoption of new and existing learning tools to fit the state of education emergency and "pass" the stress test.

The findings in this study importantly call for change in the attitude towards digital transformation and continuous work on improving students' personal innovativeness for increasing emergency remote learning acceptance. Promoting a positive attitude towards new technologies by focusing on their benefits, satisfaction and making them user-friendly will increase the acceptance of remote learning. Universities should continuously assess the satisfaction and usage of technology in remote learning to get the necessary and invaluable feedback for future evidence: grounded decision-making by all stakeholders involved in the education system and would also provide them with the tools for future stress tests that might occur. Increasing the usage of remote learning services and maximization of their benefits are imperatives since these are providing students with knowledge and skills for the new labour market. 


\section{References}

Adedoyin, B.O., Soykan, E. (2020) "Covid-19 pandemic and online learning: the challenges and opportunities", Interactive Learning Environments, https://doi.or $\mathrm{g} / 10.1080 / 10494820.2020 .1813180$.

Agarwal, R., Karahanna, E. (2000) "Time Flies When You're Having Fun: Cognitive Absorption and Beliefs About Information Technology Usage", MIS Quarterly, Vol. 24, No. 4, pp. 665-694, https://doi.org/10.2307/3250951.

Agarwal, R., Prasad, J. (1998) "A conceptual and operational definition of personal innovativeness in the domain of information technology", Information systems research, Vol. 9, No. 2, pp. 204-215, https://doi.org/10.1287/isre.9.2.204.

Ajzen, I. (1991) "The Theory of Planned Behavior", Organizational Behavior and Human Decision Processes, Vol. 50, No. 2, pp. 179-211, https://doi. org/10.1016/0749-5978(91)90020-T.

Borg, M. O., and Shapiro, S. L. (1996) "Personality type and student performance in principles of economics", Journal of Economic Education, Vol. 27, No. 1, pp. 3-25, https://doi.org/10.1080/00220485.1996.10844890.

Bouee, C. E. (2015) 'Digital Transformation Doesn't Have to Leave Employees Behind", Harvard Business Review, Available at: https://hbr.org/2015/09/digitaltransformation-doesnt-have-to-leave-employees-behind [Accessed September 28, 2021].

Bruner I.I., G. C., Kumar, A. (2005) "Explaining consumer acceptance of handheld Internet devices", Journal of business research, Vol. 58, No. 5, pp. 553-558, https://doi.org/10.1016/j.jbusres.2003.08.002.

Butler, T.J., Pinto-Zipp, G. (2005) 'Students' learning styles and their preferences for online instructional methods", Journal of Educational Technology Systems, Vol. 34, No. 2, pp.199-221, https://doi.org/10.2190/8UD2-BHFU-4PXV-7ALW.

Celik, V., Yesilyurt, E. (2013) "Attitudes to technology, perceived computer selfefficacy and computer anxiety as predictors of computer supported education", Computers \& Education, Vol. 60, No. 1, pp. 148-158, https://doi.org/10.1016/j. compedu.2012.06.008.

Chakravorti, B., Chaturvedi, R.S., Troein, C. (2017) "Building Smart Societies - A Blueprint for Action. How the World's Most Digitally Advanced Governments Offer a Strategic Choice Framework on Technology for Policymakers", The Fletcher School, Tufts University, Available at: https://sites.tufts.edu/ digitalplanet/files/2020/06/Building-Smart-Societies.pdf [Accessed September 28, 2021].

Cheng, Y.M. (2014) "Exploring the intention to use mobile learning: the moderating role of personal innovativeness", Journal of Systems and Information Technology, Vol. 16, No. 1, pp. 40-61, https://doi.org/10.1108/jsit-05-20130012. 
Chowdhury, M. S., Amin, M. N. (2006) 'Personality and students' academic achievement: interactive effects of conscientiousness and agreeableness on students' performance in principles of economics", Social Behaviour and Personality, Vol. 34, No. 4, pp. 381-388, https://doi.org/10.2224/sbp.2006.34.4.381.

Chuttur M.Y. (2009) "Overview of the Technology Acceptance Model: Origins, Developments and Future Directions", Indiana University, USA . Sprouts: Working Papers on Information Systems, SSN 1535-6078, Vol. 9, No. 37, Available at: https:/expertiseweek3.files.wordpress.com/2014/04/chuttur-2009tamreview3.pdf [Accessed September 28, 2021].

Dabbagh, N., Kitsantas, A. (2012) "Personal learning environments, social media, and self-regulated learning: a natural formula for connecting formal and informal learning", The Internet and Higher Education, Vol. 15, No. 1, pp. 3-8, https://doi.org/10.1016/j.iheduc.2011.06.002.

Davis, F. D. (1989) "Perceived usefulness, perceived ease of use, and user acceptance of information technology", MIS quarterly, Vol. 13, No 3, pp. 319340, https://doi.org/10.2307/249008.

Downing, K., Chim, T.M. (2004) "Reflectors as online extraverts?", Educational Studies, Vol. 30, No. 3, pp. 265-276. https://doi.org/10.1080/0305569042000224215.

England, I., Stewart, D. (2007) "Executive Management and IT Innovation in Health: Identifying the barriers to adoption", Health Informatics Journal, Vol. 13, No. 2, pp. 75-87, https://doi.org/10.1177/1460458207076462.

Ertmer, A.P., Ottenbreit-Leftwich, A.T. (2010) "Teacher Technology Change", Journal of Research on Technology in Education, Vol. 42, No. 3, pp. 255-284, https://doi.org/10.1080/15391523.2010.10782551.

Fagan, M., Kilmon, C., Pandey, V. (2012) "Exploring the adoption of a virtual reality simulation: The role of perceived ease of use, perceived usefulness and personal innovativeness", Campus-Wide Information Systems, Vol. 29, No. 2, pp. 117-127, https://doi.org/10.1108/10650741211212368.

Fillon, G., Dinh, Le T. (2008) "An Extended model of adoption of technology in households: A model test on people using a mobile phone", Management Review: An International Journal, Vol. 3, No. 1, pp. 58-91. Available at: https://higherlogicdownload.s3.amazonaws.com/INFORMS/a19154ba-c5e44a42-af42-0c6b23c694b8/UploadedImages/MRIJ3(1)2008(4).pdf [Accessed December 16, 2021].

Garcia-Morales, J.V., Garrido-Moreno, A., Martin-Rojas, R. (2021) "The Transformation of Higher Education After the COVID Disruption: Emerging Challenges in an Online Learning Scenario", Frontiers in Psychology, Mini Review, https://doi.org/10.3389/fpsyg.2021.616059.

Goldsmith, R. E., Hofacker, C. F. (1991) "Measuring consumer innovativeness", Journal of the academy of marketing science, Vol. 19, pp. 209-221, https://doi.org/10.1007/BF02726497. 
Goldsmith, R. E. et al. (2005) "Price sensitivity and innovativeness for fashion among Korean consumers", Journal of Social Psychology, Vol. 145, No. 5, pp. 501-508, https://doi.org/10.3200/SOCP.145.5.501-508.

Hair, J. F. et al. (2014) Multivariate Data Analysis, Harlow-Essex: Pearson Education Limited.

Hale, J., Householder, B., Greene, K. (2002) "The theory of reasoned action", pp. 259-286, Available at: http://eclipse.rutgers.edu/wp-content/uploads/ sites/51/2014/pdf/TRA\%20bk\%20ch-02.pdf [Accessed September 28, 2021].

Handel, M. et al. (2020) "Digital readiness and its effects on higher education students' socio-emotional perceptions in the context of the COVID-19 pandemic", Journal of Research on Technology in Education, https://doi.org/10. 1080/15391523.2020.1846147.

Harvey, M., Slaughter, T. (2007) "Evaluation of an access route to higher education through a work-based assessment strategy", Assessment and Evaluation in Higher Education, Vol.32, No. 1, pp. 35-43, https://doi.org/10.1080/02602930600886572.

Hatlevik, O. E., Christophersen, K.A. (2013) "Digital competence at the beginning of upper secondary school: identifying factors explaining digital inclusion", Computers \& Education, Vol. 63, pp. 240-247, https://doi.org/10.1016/j.compedu.2012.11.015.

He, T., Zhu, C. (2017) "Digital informal learning among Chinese university students: the effects of digital competences and personal factors", International Journal of Educational Technology in Higher Education, Vol. 14, No. 44, https://doi.org/10.1186/s41239-017-0082-x.

Hodges, C. et al. (2020) "The difference between emergency remote teaching and online learning", Educause Review, March 27, 2020, Available at: https://er. educause.edu/articles/2020/3/the-difference-between-emergency-remoteteaching-and-online-learning [Accessed December 16, 2021].

Hwang, Y. (2014) "User experience and personal innovativeness: An empirical study on the Enterprise Resource Planning systems", Computers in Human Behavior, Vol. 34, pp. 227-234, https://doi.org/10.1016/j.chb.2014.02.002.

Joo, Y.., Lee, H.W., Ham, Y. (2014) "Integrating user interface and personal innovativeness into the TAM for mobile learning and Cyber University", Journal of Computing in Higher Education, Vol.26, No. 2, pp. 143-158, https:// doi.org/10.1007/s12528-014-9081-2.

Kanuka, H., Nocente, N. (2003) "Exploring the effects of personality type on perceived satisfaction with web-base learning in continuing professional development", Distance Education, Vol. 24, No. 2, pp. 228-245, https://doi.org/ 10.1080/0158791032000127491.

Kegerreis, R. J., Engel, J. F., Blackwell, R. D. (1970) "Innovativeness and diffusiveness: a marketing view of the characteristics of early adopters". In D. Kollat, R. Blackwell, \& J. Engels, ed., Research in consumer behaviour, New York: Holt, Rinehold, and Winston. 
Keller, H., Karau, J.S. (2013) "The importance of personality in students' perceptions of the online learning experience", Computers in Human Behavior, Vol. 29, No. 6, pp. 2494-2500, https://doi.org/10.1016/j.chb.2013.06.007.

Khan, M., Iahad, N., Miskon, S. (2011) "Exploring the Influence of Big Five Personality Traits towards Computer Based Learning (CBL) Adoption", Journal of Information Systems Research and Innovation, Vol. 8, pp. 1-8. Available at: https://seminar.utmspace.edu.my/jisri/download/Special\%20Issue-Dec2014/ Exploring\%20the\%20Influence.pdf [Accessed December 16, 2021].

Lai, C., Wang, Q., Lei, J. (2012) “What factors predict undergraduate students' use of technology for learning? A case from Hong Kong", Computers \& Education, Vol. 59, No. 2, pp. 569-579, https://doi.org/10.1016/j.compedu.2012.03.006.

Leavitt, C., Walton. J. (1975) "Development of a scale for innovativeness". In Schlinger, M.J. ed., NA-Advances in Consumer Research, Vol. 2, pp. 545-554, Available at: http://www.acrwebsite.org/search/view-conference-proceedings. aspx?Id=5781[Accessed September 28, 2021].

Lee, J.M., Lee, Y. (2006) "Personality types and learners' interaction in web-based threaded discussion", Quarterly Review of Distance Education, Vol. 7, No. 1, pp. 83-94. Available at: https://eric.ed.gov/?id=EJ875026 [Accessed December $16,2021]$.

Lin, H., Hwang, Y. (2014) "Do feelings matter? The effects of intrinsic benefits on individuals' commitment toward knowledge systems", Computers in Human Behavior, Vol. 30, No. 1, pp. 191-198, https://doi.org/10.1016/j.chb.2013.07.056.

Liu, Y., Li, H., Carlsson, C. (2010) "Factors driving the adoption of m-learning: An empirical study", Computers \& Education, Vol. 55, No. 3, pp. 1211-1219, https://doi.org/10.1016/j.compedu.2010.05.018.

Lu, J., Yao, J. E., Yu, C. S. (2005) "Personal innovativeness, social influences and adoption of wireless Internet services via mobile technology", The Journal of Strategic Information Systems, Vol. 14, No. 3, pp. 245-268, https://doi. org/10.1016/j.jsis.2005.07.003.

Markauskaite, L. (2006) "Exploring differences in trainee teachers' ICT literacy: does gender matter", Australian Journal of Educational Technology, Vol.22, No. 1, pp. 445-455. Available at: https://www.ascilite.org/conferences/ brisbane05/blogs/proceedings/51_Markauskaite.pdf [Accessed December 16, 2021].

McCarthy, J., Wright, P. (2004) “Technology as Experience", Interactions, Vol. 11, No. 5, pp. 42-43, https://doi.org/10.1145/1015530.1015549.

Meyers, E. M., Erickson, I., Small, R. V. (2013) "Digital literacy and informal learning environments: an introduction. Learning", Media and Technology, Vol. 38, No. 4, pp. 355-367, https://doi.org/10.1080/17439884.2013.783597.

Milman, N. B. (2020) "This is emergency remote teaching, not just online teaching", Education Week, Available at: https://www.edweek.org/leadership/ 
opinion-this-is-emergency-remote-teaching-not-just-online-teaching/2020/03 [Accessed: September 28, 2021].

OECD (2020) "Education responses to covid-19: Embracing digital learning and online collaboration", OECD, Available at: https://read.oecd-ilibrary.org/ view/?ref=120_120544-8ksud7oaj2\&title=Education_responses_to_Covid-19_ Embracing_digital_learning_and_online_collaboration [Accessed September 28, 2021].

OECD (2021) "The State of School Education. One Year into the Covid Pandemic", OECD Publishing, Paris. Available at: https://doi.org/10.1787/201dde84-en [Accessed: September 28, 2021].

Ozbek, V. et al. (2014) "The Impact of Personality on Technology Acceptance: A Study on Smart Phone Users", Procedia - Social and Behavioral Sciences, Vol. 150, No. 15, pp. 541-551. https://doi.org/10.1016/j.sbspro.2014.09.073.

Park, S. Y. (2009) "An analysis of the technology accept ance model in understanding university students' behavioral intention to use e-learning", Educational Technology \& Society, Vol. 12, pp. 150-162, https://doi. org/10.1111/j.1467-8535.2011.01229.x.

Park, S. Y., Nam, M.W., Cha, S.B. (2012) “University students' behavioral intention to use mobile learning: evaluating the technology acceptance model", British Journal of Educational Technology, Vol. 43, No.4, pp. 592-605, https://doi. org/10.1111/j.1467-8535.2011.01229.x.

Poropat, A.E. (2009) "A meta-analysis of the five-factor model of personality and academic performance", Psychological Bulletin, Vol. 135, No. 2, pp. 322-338, https://doi.org/10.1037/a0014996

Raaij, van, E. M., Schepers, J. J. L. (2008) "The acceptance and use of a virtual learning environment in China", Computers and Education, Vol. 50, No. 3, pp. 838-852, https://doi.org/10.1016/j.compedu.2006.09.001.

Rammstedt, B., John, O. P. (2007) "Measuring personality in one minute or less: A 10-item short version of the Big Five Inventory in English and German", Journal of Research in Personality, Vol. 41, pp. 203-212, https://doi. org/10.1016/j.jrp.2006.02.001.

Rapanta, C. et al. (2020) "Online university teaching during and after the covid-19 crisis: Refocusing teacher presence and learning activity", Postdigital Science and Education, Vol. 2, pp. 1-23, https://doi.org/10.1007/s42438-020-00155-y.

Rodriguez-Ardura, I., Meseguer-Artola, A. (2016) "What leads people to keep on e-learning? An empirical analysis of users' experiences and their effects on continuance intention", Interactive Learning Environments, Vol. 24, No. 6, pp. 1030-1053, https://doi.org/10.1080/10494820.2014.926275.

Rogers, E. (1962) Diffusion of Innovations, 1st edition. New York, NY, Free Press. Rogers, E. (1995) Diffusion of Innovations, 4th edition. New York, NY, Free Press. Rogers, E. (2003) Diffusion of Innovations, 5th edition. New York, NY, Free Press. 
Rogers, E.M., Shoemaker, F.F. (1971a) Communication of Innovation: A CrossCultural Approach, 2nd Edition. New York, NY, Free Press.

Rogers, E.M., Shoemaker, F. (1971b) Diffusion of innovations. 2nd Edition. New York, NY, Free Press.

Rovai, A.P. (2003) "The relationships of communicator style, personality-based learning style, and classroom community among online graduate students", Internet and Higher Education, Vol. 6, No. 4, pp. 347-363, https://doi. org/10.1016/j.iheduc.2003.07.004.

Samaradiwakara, G.D.M.N., Gunawardena, C. (2014) "Comparison of existing technology acceptance theories and models to suggest a well improved theory/ model", International Technical Science Journal, Vol. 1, pp. 21-36. Available at: http://elpjournal.eu/wp-content/uploads/2016/03/itsj-spec-1-1-3.pdf [Accessed December 16, 2021].

Schniederjns, M.J., Kim, E.B. (2005) "Relationship of student undergraduate achievement and personality characteristics in a total web-based environment: an empirical study", Decision Sciences Journal of Innovative Education, Vol. 3, No. 2, pp. 205-221, https://doi.org/10.1111/j.1540-4609.2005.00067.x.

Thatcher, J. B., Perrewe, P. L. (2002) "An empirical examination of individual traits as antecedents to computer anxiety and computer self-efficacy", MIS quarterly, Vol. 26, No. 4, pp. 381-396, https://doi.org/10.2307/4132314.

Tolba, A. H., Mourad, M. (2011) "Individual and cultural factors affecting diffusion of innovation", Journal of International Business \& Cultural Studies, Vol. 5, No.1, pp. 1-16. Available at: http://www.aabri.com/manuscripts/11806.pdf [Accessed December 16, 2021]

Ungerer, L. M. (2016) "Digital Curation as a Core competency in current learning and literacy: a higher education perspective", The International Review of Research in Open and Distributed Learning, Vol. 17, No. 5, https://doi. org/10.19173/irrodl.v17i5.2566.

Vekantesh, V. (2000) "A Theoretical Extenwsion of the Technology Acceptance Model: Four Longitudinal Field Studies", Management Science, Vol. 46, No. 2 , pp. 186-204, https://doi.org/10.1287/mnsc.46.2.186.11926.

Venkatesh, V. et al. (2003) "User acceptance of information technology: toward a unified view", MIS Quarterly, Vol. 27, No. 3, pp. 425-478, https://doi. org/10.2307/30036540.

Venkatesh, V., Thong, L.Y., Xu, X. (2012) "Consumer Acceptance and Use of Information Technology: Extending the Unified Theory of Acceptance and Use of Technology", MIS Quarterly, Vol. 36, No. 1, pp. 157-178, https://doi. org/10.2307/41410412.

Zhou, J., George, J. M. (2001) "When job dissatisfaction leads to creativity: Encouraging the expression of voice", Academy of Management Journal, Vol. 44, No. 4, pp. 682-696. https://doi.org/10.5465/3069410. 


\title{
Hitno prihvaćanje učenja na daljinu među studentima visokog obrazovanja
} tijekom pandemije COVID-19

\author{
Amila Pilav-Velić ${ }^{1}$, Hatidža Jahićn ${ }^{2}$,Jasmina Okičićc ${ }^{3}$, Jasmina Selimović ${ }^{4}$, \\ Elvedin Grabovica ${ }^{5}$
}

\begin{abstract}
Sažetak
Trenutna studija istražuje kako stavovi prema digitalnoj transformaciji i osobnoj inovativnosti utječu na prihvaćanje hitnog učenja na daljinu u okruženju pandemije COVID-19. Pandemija je utjecala na sve aspekte društava diljem svijeta, uključujući visoko obrazovanje, a također je bila značajan poticajni čimbenik za digitalnu transformaciju visokog obrazovanja. Stoga je glavni cilj ovog rada istražiti čimbenike koji utječu na hitno prihvaćanje učenja na daljinu među studentima visokog obrazovanja u Bosni i Hercegovini (BiH). Rezultati prikazani u ovom radu izvedeni su iz istraživanja koje je provedeno među studentima visokog obrazovanja u BiH u razdoblju od travnja do srpnja 2020. godine putem otvorene web platforme. Studija je pokazala da je stav učenika prema digitalnoj transformaciji značajan čimbenik u prihvaćanju hitnog učenja na daljinu. Također, ocjena osobne inovativnosti pokazala se značajnim čimbenikom u prihvaćanju ove nove postavke učenja, tj. inovativniji učenici imaju veće prihvaćanje učenja na daljinu u hitnim slučajevima od učenika s nižim rezultatom osobne inovativnosti. Stoga ova studija ukazuje na potrebu promjene stavova prema korištenju tehnologije u obrazovanju. Time bi se povećala upotreba usluge učenja na daljinu te studentima pružila znanja i vještine za novo tržište rada.
\end{abstract}

Ključne riječi: osobna inovativnost, učenje na daljinu, digitalna transformacija, studenti, COVID-19

JEL klasifikacija: I21, I23, O33, O36

1 Izvanredna profesorica, Ekonomski fakultet, Univerzitet u Sarajevu, Trg oslobođenja - Alija Izetbegović 1, 71000 Sarajevo, Bosna i Hercegovina. Znanstveni interes: inovacijski menadžment, otvorene inovacije.Tel.: +38733253771.E-mail: amila.pilav-velic@efsa.unsa.ba.

2 Docentica, Ekonomski fakultet, Univerzitet u Sarajevu, Trg oslobođenja - Alija Izetbegović 1, 71000 Sarajevo, Bosna i Hercegovina. Znanstveni interes: obrazovanje, razvojna ekonomija. Tel.:+38733253776.E-mail: hatidza.jahic@efsa.unsa.ba.

${ }^{3}$ Izvanredna profesorica, Ekonomski fakultet, Univerzitet u Tuzli, Univerzitetska 8, 75000 Tuzla, Bosna i Hercegovina. Tel.: +3876030444419. Znanstveni interes: kvantitativna ekonomija. E-mail: jasmina.okicic@unitz.ba.

${ }^{4}$ Redovna profesorica, Ekonomski fakultet, Univerzitet u Sarajevu, Trg oslobođenja - Alija Izetbegović 1, 71000 Sarajevo, Bosna i Hercegovina. Znanstveni interes: financije, osiguranje. Tel.: +387332759921.E-mail: jasmina.selimovic@efsa.unsa.ba.

5 Docent, Ekonomski fakultet, Univerzitet u Sarajevu, Trg oslobođenja - Alija Izetbegović 1, 71000 Sarajevo, Bosna i Hercegovina. Znanstveni interes: informacijski sustavi. Tel.: +38733275900.E-mail: elvedin.grabovica@efsa.unsa.ba. 